\title{
PENERAPAN STRATEGI ARCS DENGAN PEMBERIAN SCAFFOLDING : UPAYA MENINGKATKAN KEMAMPUAN PEMAHAMAN MATEMATIKA DAN PEMBENTUKAN KARAKTER MAHASISWA PADA MATA KULIAH MATEMATIKA DASAR
}

\author{
APPLICATION OF ARCS'S STRATEGY WITH GIVING SCAFFOLDING: EFFORT TO INCREASE \\ MATHEMATICAL UNDERSTANDING ABILITY AND BUILD CHARACTER OF \\ UNDERGRADUATE IN MATHEMATICS FOUNDATION
}

\author{
Henny Ekana Chrisnawati, Budi Usodo, Ira Kurniawati, Yemi Kuswardi \\ Program Studi Pendidikan Matematika FKIP UNS
}

\begin{abstract}
ABSTRAK
Penelitian ini bertujuan untuk meningkatkan kemampuan pemahaman matematika mahasiswa dan karakter belajar mahasiswa pada mata kuliah Matematika Dasar dengan menggunakan strategi pembelajaran ARCS dengan pemberian scaffolding. Sifat abstrak materi pada mata kuliah tersebut dan perlunya kemampuan pemahaman baik komputasional maupun fungsional menjadi salah satu yang menjadi pemikiran penelit. Karakter konsep matematika yang bersifat seperti piramida mengharuskan pebelajar menguasai konsep dasarnya dengan baik untuk menuju pemahaman konsep yang baru.Selain kemampuan pemahaman, pembentukan karakter juga menjadi salah satu faktor afektif penting bagi keberhasilan seseorang dalam belajar matematika. Dengan memperhatikan perkembangan karakter, diharapkan mahasiswa mampu menunjukkan karakter positif dalam belajar sehingga berimplikasi positif pula terhadap hasil belajarnya. Penelitian ini merupakan penelitian tindakan kelas yang mampu memberikan informasi tentang perubahan maupun peningkatan yang disebabkan oleh suatu tindakan. Adapun subyek penelitian tersebut adalah mahasiswa Prodi Pendidikan Fisika FKIP UNS tahun ajar 2015/2016. Sedangkan untuk teknik pengumpulan data digunakan teknik tes dan observasi, dimana instrumen pembelajaran dan penelitian dikembangkan dengan divalidasi oleh professional judgment.Adapun hasil dari penerapan pembelajaran dengan strategi ARCS dengan pemberian scaffolding ini adalah adanya peningkatan kemampuan pemahaman matematika. Hal ini terbukti dari hasil tes kemampuan pemahaman siklus I dan siklus II, yang menunjukkan bahwa prosentase ketuntasan hasil kemampuan pemahaman akan konsep matematika mahasiswa meningkat dari 39, $5 \%$ menjadi 77,4\% (pada siklus 1) dan 82,6\% (pada siklus 2). Begitupun pada rerata hasil yang menunjukkan peningkatan dari 61 pada siklus 1 menjadi 81,1 pada siklus 2. Penerapan strategi pembelajaran tersebut juga meningkatkan hasil belajar afektif mahasiswa yakni pembentukan karakter belajar mahasiswa. Hal ini terbukti dari hasil observasi siklus I dan hasil observasi siklus II bahwa rata-rata prosentase pembentukan karakter belajar untuk indikator : karakter jujur, disiplin, kerja keras, kreatif, mandiri, demokratis, memiliki rasa ingin tahu, menghargai prestasi, bersahabat, tanggung jawab yang dikembangkan meningkat dari kategori rendah saat pra siklus menjadi sedang pada siklus 2 dan tinggi saat siklus 2. Ini berarti dengan menggunakan teknik motivasi (attention, relevance, confidence dan satisfaction) pada kegiatan pembelajaran matematika dasar, ternyata memenuhi kebutuhan mahasiswa dalam mencapai prestasi belajar yang optimal.
\end{abstract}

Kata Kunci: kemampuan pemahaman konsep, karakter, strategi ARCS, scaffolding.

\begin{abstract}
This research has purposes to increase mathematical understanding ability and build character of undergraduate in mathematics foundation which uses ARCS's strategy with giving scaffolding. Mathematics foundation which has abstract's characteristic and necessary from understanding ability both computational also fungtional become priority of researcher's thought. Characteristic of mathematical concept which is pyramidal compel students to understanding basic concept correctly for the sake of understanding new concept. Not only for understanding but also building character is one of affectionate factors priority to reach success in learning mathematics. Pay attention of developing character, undergraduate are wished to show positively character in learning so that gives positively implication to the results. This research is classroom activity research which gives some informations about the changes or increase that ae caused by an activity. This research uses undergraduate of physics education in year academic 2015/2016 as a subject. Technique of collecting data uses test and observation while learning and research's instrument is developed by validation of professional judgment. The result from application of ARCS's strategy with giving scaffolding in learning is exist an increase of mathematical understanding ability. It showed by the results of mathematical understanding ability's test in first and second cycle which gave information that there exist an increase of completeness percentage for understanding mathematical concept which from 39, $5 \%$ up to 77,4\% in first cycle then continued up to 82,6 \% in second cycle. Like that, it also showed by the mean of the test's result which gave an increase from 61 in first cycle up to 81,1 in second cycle. The application of ARCS's strategy also increased the affectionate learning's result. It showed by the results of observation in first and second cycle which showed that the mean percentage of character building from indicators: honest, discipline, hardworking, creative, stand alone, has a curiosity, appreciate achievement, friendly, respon sible which were developed. Those results increase from bottom category in pre-cycle became in middle and high category in second cycle. It means that used motivation technique (attention, relevance, confidence and satisfaction) in learning activity of mathematics foundation gave fact that those technique fulfilled need of undergraduate for reaching optimal achievement.
\end{abstract}

Keywords : understanding concept ability, character, ARCS's strategy, scaffolding 


\section{PENDAHULUAN}

Matematika Dasar merupakan salah satu matakuliah wajib di seluruh program studi pendidikan di Pendidikan Fisika FKIP UNS, mata kuliah tersebut diberikan pada semester I dengan bobot 3 SKS. Tujuan perkuliahan Matematika Dasar adalah memberikan pemahaman dasar kepada mahasiswa mengenai pengetahuan dasar matematika seperti limit, kontinuitas, turunan, integral suatu fungsi serta aplikasinya. National Science Teachers Association (NSTA) dan Permendiknas No 16 Tahun 2007 merekomendasikan bahwa guru-guru IPA sekolah menengah harus memiliki kecenderungan interdisipliner pada sains (IPA) atau integrated science. Juga disebutkan bahwa kompetensi guru mata pelajaran IPA SMP/MTs salah satunya adalah memahami hubungan antar berbagai cabang IPA, dan hubungan IPA dengan matematika dan teknologi. Dari rekomendasi Permendiknas dan NSTA tersebut, dapat dikatakan kompetensi matematika mahasiswa LPTK pada Pendidikan MIPA mutlak diperlukan. Sehubungan dengan pentingnya peranan matematika, maka sudah seharusnya proses pembelajaran matematika ditangani lebih serius. Pendidik perlu mempersiapkan suatu model pembelajaran yang terprogram agar peserta didik memperoleh pengalaman belajar yang baik, yang dapat meningkatkan motivasi belajar siswa dan keaktifan siswa, serta mampu membentuk kepribadian positif.

Materi pada mata kuliah tersebut bukanlah materi baru. Di jenjang pendidikan SMA, mahasiswa sudah mengenal materi-materi tersebut. Namun pada kenyataanya, berdasar informasi dari anggota Research Group, masih terdapat mahasiswa yang mengalami kesulitan dalam belajar materi matematika dasar.

Tabel.1 Data Dari Pengampu Matematika Dasar di Prodi Pendidikan Fisika tahun 2014/2015.

\begin{tabular}{|c|c|c|c|c|}
\hline $\begin{array}{l}\text { Jumlah } \\
\text { mahasiswa yang } \\
\text { mengikuti } \\
\text { perkuliahan }\end{array}$ & $\begin{array}{lr}\text { Yang mengikuti } \\
\text { Remidi } \\
\text { materi UKD1 }\end{array}$ & $\begin{array}{lr}\text { Yang mengikuti } \\
\text { Remidi pada } \\
\text { materi UKD2 }\end{array}$ & $\begin{array}{l}\text { Yang mengikuti } \\
\text { Remidi pada } \\
\text { materi UKD3 }\end{array}$ & $\begin{array}{l}\text { Yang mengikuti } \\
\text { Remidi pada } \\
\text { materi UKD4 }\end{array}$ \\
\hline Kelas $A=34$ & $44 \%$ & $47 \%$ & $50 \%$ & $35,3 \%$ \\
\hline Kelas B $=24$ & $61 \%$ & $21,7 \%$ & $82,6 \%$ & $26 \%$ \\
\hline
\end{tabular}

Hal demikian tentunya memunculkan pertanyaan, ada permasalahan apa dengan kemampuan pemahaman mahasiswa? Bukankah materi pada matakuliah tersebut bukan hal yang baru? Materi matematika dasar yang sifatnya abstrak dimungkinkan membuat mahasiswa mengalami kesulitan pemahaman dalam belajar. Meski dalam tahapan Bruner, seharusnya mahasiswa sudah pada tahapan simbolik. Pembelajaran umum matematika, yang dirumuskan oleh NCTM menggariskan, peserta didik harus mempelajari matematika melalui pemahaman dan aktif membangun pengetahuan baru dari pengalaman dan pengetahuan yang dimiliki sebelumnya. Sedangkan pengetahuan dan pemahaman siswa terhadap konsep matematika menurut NCTM (1989) dapat dilihat dari kemampuan siswa dalam: (1) Mendefinisikan konsep secara verbal dan tulisan; (2) Mengidentifikasi dan membuat contoh dan bukan contoh; (3) Menggunakan model, diagram dan simbol-simbol untuk merepresentasikan suatu konsep; (4) Mengubah suatu bentuk representasi ke bentuk lainnya; (5) Mengenal berbagai makna dan interpretasi konsep; (6) Mengidentifikasi sifat-sifat suatu konsep dan mengenal syarat yang menentukan suatu konsep; (7) Membandingkan dan membedakan konsep-konsep. Kemampuan pemahaman matematis adalah salah satu tujuan penting dalam pembelajaran. Bahkan dalam Permendiknas Nomor 22 Tahun 2006, salah satu tujuan dari pembelajaran matematika adalah 
mengembangkan kemampuan pemahaman konsep. Bloom mengklasifikasikan pemahaman (Comprehension) ke dalam jenjang kognitif kedua yang menggambarkan suatu pengertian sehingga siswa diharapkan mampu memahami ide-ide matematika bila mereka dapat menggunakan beberapa kaidah yang relevan. Dengan kemampuan pemahaman konsep yang baik, maka menurut NCTM daya matematika (mathematical power) seseorang juga akan berkembang. Pemahaman akan konsep merupakan bagian terpenting dari proses pembelajaran. Dengan pemahaman yang baik maka akan memberikan kebermaknaan dan dasar bagi konsep berikutnya dalam belajar matematika.. Kemampuan inilah yang ingin peneliti tingkatkan karena urgensinya pada kompetensi mahasiswa dalam belajar matematika dan ilmu lain yang berkaitan pada umumnya.

Hal lain yang juga menjadi pertimbangan adalah pembentukan karakter belajar pada mahasiswa. Karena materi pada mata kuliah matematika dasar sebagian sudah diterima mahasiswa saat di bangku SMA, namun pada tabel di atas menunjukkan adanya permasalahan dalam pencapaian hasil belajar, maka perlu peneliti juga melihat faktor lain yang berpengaruh terhadap hasil belajar, yakni faktor afektif. Karakter belajar merupakan faktor afektif yang juga mendukung keberhasilan seseorang dalam belajar. Pendidikan Karakter merupakan bentuk kegiatan manusia yang di dalamnya terdapat suatu tindakan yang mendidik diperuntukkan bagi generasi selanjutnya. Tujuan pendidikan karakter adalah untuk membentuk penyempurnaan diri individu secara terus-menerus dan melatih kemampuan diri demi menuju kearah hidup yang lebih baik (Wikipedia). Di dasarkan pada INPRES Republik Indonesia Nomor 1 Tahun 2010 tentang Percepatan Pelaksanaan Prioritas Pembangunan Nasional Tahun 2010 yang mengamanatkan program penguatan metodologi dan kurikulum dengan cara menyempurnakan kurikulum dan metode pembelajaran aktif berdasarkan nilai-nilai budaya bangsa untuk membentuk daya saing dan karakter bangsa. Melalui kegiatan perkuliahan dapat mengembangkan karakter positif dalam belajar. Karakter positif untuk belajar diharapkan mampu membentuk mahasiswa yang mengikuti kuliah Matematika Dasar tersebut, yang notabene masih duduk di semester awal pendidikan di perguruan tinggi menjadi mahasiswa yang berkecerdasan budi, yang sesuai dengan visi "Berkarakter Kuat dan Cerdas".

Pembentukan karakter tidak hanya penting untuk menjadikan siswa terlibat dalam kegiatan akademik, namun juga sangat berperan dalam menentukan seberapa jauh siswa akan termotivasi untuk belajar dari suatu kegiatan pembelajaran. Gardner, dkk (dalam Nur, 1998) mengemukakan bahwa: "siswa termotivasi untuk belajar sesuatu akan menggunakan proses kognitif yang lebih tinggi dalam mempelajari materi itu, sehingga siswa itu akan menyerap dan mengendapkan materi itu dengan lebih baik.

Untuk dapat mencapai tujuan tersebut diperlukan suatu strategi untuk meningkatkan motivasi siswa terhadap materi pembelajaran. Keller (1987) memperkenalkan suatu strategi motivasi ARSC (Attention, Relevance, Confidence, Satisfaction). Selanjutnya Keller (dalam https://sphweb.bumc.bu.edu) mengemukakan bahwa: "strategi motivasi model ARCS adalah suatu metode untuk meningkatkan motivasi terhadap materi pembelajaran". Dalam hal ini strategi motivasi ARCS memiliki strategi yang dapat digunakan untuk meningkatkan motivasi, dan aktivitas siswa dalam belajar. Dalam strategi motivasi ARCS terdapat kiat-kiat sebagai berikut. (1) Untuk meningkatkan perhatian siswa terhadap materi pelajaran; (2) menghubungkan materi dengan manfaatnya dalam kehidupan seharihari; (3) untuk meningkatkan kepercayaan siswa terhadap materi yang diberikan guru; dan (4) untuk mewujudkan kepuasan siswa dalam proses pembelajaran dan materi yang dipelajarinya. 
Penerapan motivasi dalam Pendidikan dan Pembelajaran ( Martini Jamaris, 2013:180)

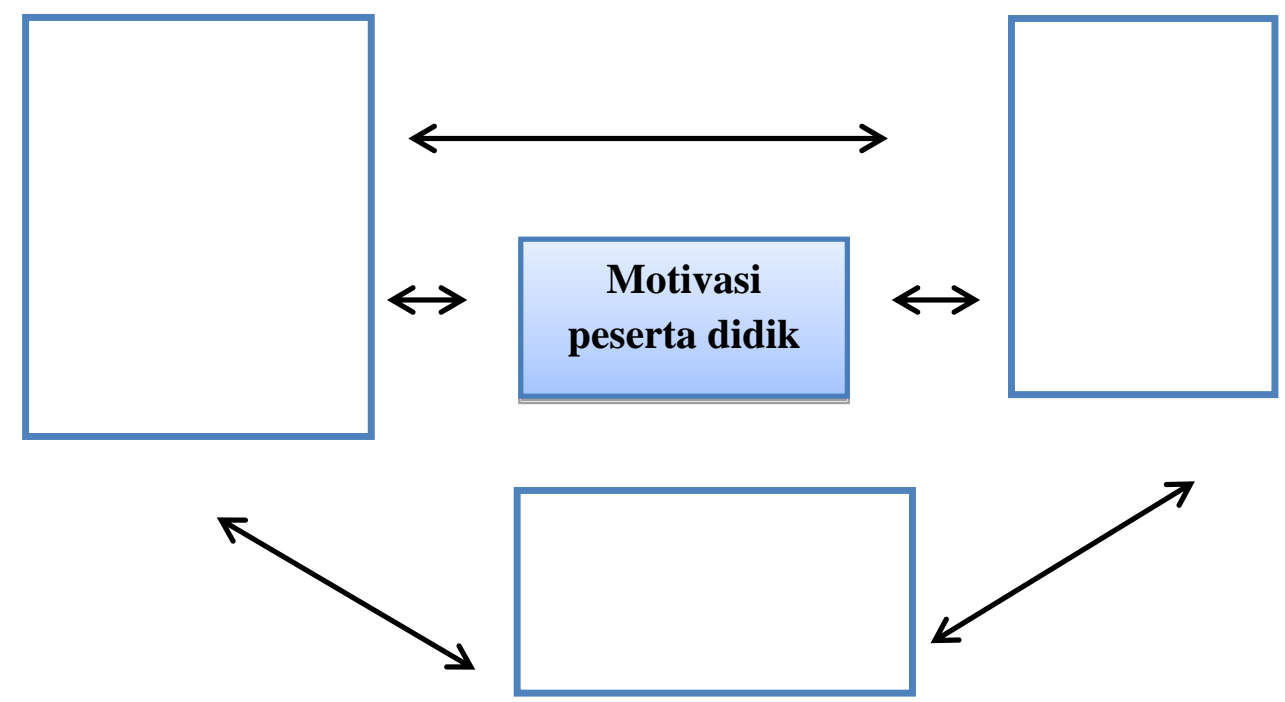

Penerapan startegi ARCS tersebut oleh penulis didesain juga dengan pemberian scaffolding dengan memberiakan hand out yang didesain untuk membantu mahasiswa belajar. Menurut Brunner, scaffolding sebagai suatu proses dimana seorang siswa dibantu menuntaskan masalah tertentu melampaui kapasitas perkembangannya melalui bantuan dari guru atau orang lain yang memiliki kemampuan lebih. Dari definisi yang telah dijelaskan di atas dapat disimpulkan bahwa scaffolding merupakan bantuan, dukungan (support) kepada siswa yang memungkinkan siswa mengembangkan daya kognitifnya lebih tinggi yang ditunjukkan dengan adanya kemampuan penyelesaian soal yang lebih.

Berdasarkan uraian di atas peneliti merumuskan pemasalahan tentang bagaimana penerapan pembelajaran strategi ARCS dengan pemberian scaffolding pada perkuliahan matematika dasar dan apakah penerapan pembelajaran penerapan pembelajaran strategi ARCS dengan pemberian scaffolding dapat meningkatkan kemampuan pemahaman matematika dan pembentukan karakter belajar mahasiswa peserta mata kuliah matematika dasar.

\section{METODOLOGI}

Strategi penelitian yang akan digunakan adalah penelitian tindakan kelas (classroom action research)yang direncanakan terdiri dari dua siklus. Penelitian tindakan kelas bertujuan untuk mengmbangkan strategi pembelajaran yang paling efektif dan efisien pada situasi yang alamiah (Endang Mulyatiningsih, 2012). Dalam penelitian tindakan kelas akan diperoleh informasi tentang perubahan maupun peningkatan yang disebabkan oleh suatu tindakan, karena tujuan dari penelitian tindakan kelas sendiri adalah untuk memperbaiki kinerja didasarkan pada evaluasi diri peneliti. Penelitian tersebut juga merupakan penelitian kelas kolaboratif. Penelitian tersebut dilakukan di kelas matematika dasar pada mahasiswa program studi Pendidikan Fisika tahun ajar 2015/2016.

Adapun penelitian tersebut direncanakan dalam dua siklus, dengan tahapan dalam pelaksanaan PTK adalah (1) tahapan perencanaan, pada tahapan perencanaan, akan dibuat rancangan pembelajaran dengan strategi ARCS dengan pemberian scaffolding. Rancangan pembelajaran tersebut menuntut perencanaan dalam RPP, hand out pembelajaran, jenis tugas yang mengungkap kemampuan pemahaman matematika, dan karakter belajar mahasiswa. 
Instrumen yang diperlukan berupa lembar observasi dan tes, (2) Tahapan pelaksanaan tindakan. Pada tahapan ini akan dilaksanakan proses pembelajaran sesuai dengan perencanaan yang dibuat dengan mengemukakan hipotesis " Pembelajaran dengan strategi ARCS dengan pemberian scaffolding dapat meningkatkan kemampuan pemahaman matematika dan karaketr belajar mahasiswa pada mata kuliah matematika dasar“. (3) Tahapan observasi dan interpretasi, pada tahapan observasi dan interpretasi, tim peneliti akan memantau pelaksanaan pembelajaran dan dampak pembelajaran tersebut untuk kemudian digunakan dalam langkah selanjutnya. Pemantauan pelaksanaan pembelajaran dilakukan dengan observasi di kelas. (4) Tahapan analisis dan refleksi. Pada tahapan analisis dan refleksi, hasil yang diperoleh pada tahapan observasi maupun dari tes dikumpulkan dan dianalisis oleh anggota peneliti dalam research group, untuk kemudian dilakukan refleksi untuk melihat kekurangan atau kelemahan yang telah terjadi. Tahapan tersebut akan dilakukan lagi pada siklus ke dua, jika indikator kinerja keberhasilan penelitian belum tercapai. Untuk pengambaran tahapan penelitian adalah sebagai berikut :

Observasi awal perkuliahan Matematika Dasar

di Prodi Pendidikan Fisika PMIPA UNS
SIKLUS 1
Perencanaan Tindakan 1: Pembelajaran dengan strategi ARCS dengan pemberian scaffolding untuk pemahaman dan observasi karakter mahasiswa guna keberhasilan studi mahasiswa di perguruan tinggi

- Skor tes siklus 1

- Hasil observasi karakter belajar mahasiswa

- Kekurangan/reflleksi saat pelaksanaan_nembelajaran

1

\section{Perencanaan Tindakan 1I: \\ I Pembelajaran dengan \\ I strategi ARCS dengan I pemberian scaffolding}

I
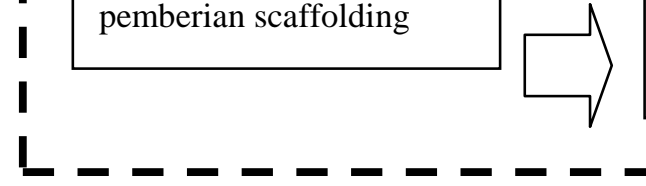

Analisis Data 1:

Analisis hasil tes mahasiswa, analisis hasil observasi terhadap karakter belajar mahasiswa dan kegiatan perkuliahan

\section{SIKLUS 2}

Pelaksanan Tindakan II: Pelaksanaan pembelajaran sesuai dengan rencana tindakan

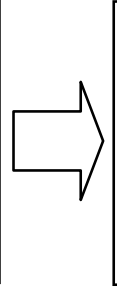

Pelaksanaan Tindakan 1: Pembelajaran dengan strategi ARCS dengan pemberian scaffolding untuk pemahaman dan observasi karakter mahasiswa

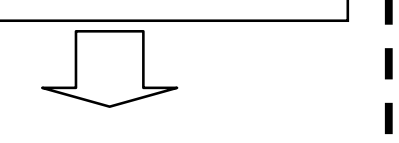

Observasi 1:

Pengamatan pelaksanaan perkuliahan

Memberikan tes siklus 1

Observasi karakter

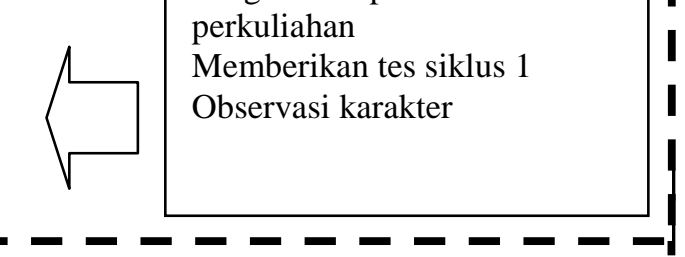

Observasi II:

Pengamatan pelaksanaan perkuliahan

Memberikan tes siklus 2

Observasi karakter

Dari tahapan-tahapan tersebut, diharapkan pada akhir siklus ke 2 mahasiswa menunjukkan peningkatan hasil belajar yakni mulai terbentuknya karakter belajar yang positif dan kemampuan pemahaman konsep matematika pada kategori tinggi.

Adapun indikator keberhasilan yang digunakan 
- Untuk kemampuan pemahaman mahasiswa, dengan desain tes yang mengungkap pemahaman baik komputasional maupun fungsional, didasarkan pada keputusan rapat Program Studi Pendidikan Matematika, maka indikator keberhasilan pada kemampuan pemahaman konsep tersebut adalah $75 \%$ dari jumlah peserta mata kuliah tuntas, dimana interval nilai didasarkan pada SK Rektor UNS Nomor 644/UN27/HK/2015

- Untuk indikator keberhasilan pada karakter belajar mahasiswa adalah didasarkan pada analisis hasil pengamatan pembentukan karakter. Skor 1 jika karakter belajar tampak dari 75\% mahasiswa dan skor 0 “ jika jumlah respon dari indikator karakter belajar yang ditunjukkan mahasiswa kurang dari $75 \%$ jumlah peserta. Selanjutnya akan dihitung prosentase hasil observasi dengan rumus berikut :

$$
\mathrm{P}=\frac{\text { Skor capaian }}{\text { skor maksimal }} \times 100 \%
$$

Indikator kinerja yang digunakan dalam penelitian tersebut untuk karakter belajar adalah dalam kategori " tinggi “. Untuk pedoman kriteria hasil observasi digunakan kriteria menurut Suharsimi Arikunto dan Safrudin Ceppi (2008), yakni kategori rendah (untuk $0 \% \leq \mathrm{p} \leq 33,33 \%$ ), sedang untuk 33,34 $\% \leq \mathrm{p} \leq 66,67 \%$, dan tinggi untuk 66,67 $\% \leq \mathrm{p} \leq 10033 \%$.

\section{PEMBAHASAN}

Menurut Slametto ( 1995) terdapat beberapa faktor baik langsung ataupun tidak langsung yang berpengaruh terhadap prestasi belajar siswa, baik faktor intern maupun ekstern peserta didik. Dinyatakan juga faktor-faktor yang mempengaruhi proses belajar mengajar pada akhirnya juga sangat mempengaruhi prestasi belajar siswa, di antaranya :

- Model pembelajaran yang digunakan dalam pembelajaran.

Dalam memilih model pembelajaran harus disesuaikan dengan banyak faktor diantaranya karakteristik materi itu sendiri. Pemilihan model pembelajaran yang tepat dapat meningkatkan kualitas proses pembelajaran baik dari sisi pengajar maupun dari sisi pebelajar. Untuk dapat mengajar lebih efektif, dan membuat peserta didik merasa tidak merasa berat dalam belajar, pendidik harus selalu berusaha untuk memvariasikan proses pembelajaran sehingga dapat membangkitkan motivasi belajar siswa.

- Pembentukan karakter belajar pada mahasiswa

Tidak dipungkiri sebagai karakter belajar adalah faktor afektif yang karakter belajar positif terhadap matematika mutlak diperlukan untuk mendukung keberhasilan kemampuan kognitifnya.

Kegiatan observasi awal dilakukan pada awal perkuliahan tanggal 2 September 2015 dengan melaksanakan observasi aktivitas mahasiswa saat perkuliahan yang berkaitan dengan karakter belajar mahasiswa. Perkuliahan dimulai dengan materi review konsep bilangan riil, review konsep fungsi dan Tes awal. Adapun kondisi awal kelas sebelum dikenakan tindakan dengan pembelajaran strategi ARCS dengan pemberian scaffolding adalah sebagai berikut :

- Untuk disiplin, semua mahasiswa menunjukkan perilaku tertib dan patuh dengan ketentuan jam kuliah yang berlaku.

- Saat pengampu akan mengadakan tes setelah pembelajaran, mahasiswa banyak menolak dengan alasan belum siap. Padahal materi yang akan diujikan adalah materi yang diberikan pada perkuliahan saat itu yakni sistem 
bilangan real dan persamaan dan pertidaksamaan yang notabene adalah materi yang telah pula diterima mahasiswa saat di bangku SMA maupun SMP.

- Masih rendahnya rasa ingin tahu mahasiswa yang ditunjukkan dengan tidak banyak mahasiswa yang bertanya saat diberikan kesempatan untuk bertanya jawab baik dengan pengampu maupun teman dan kurangnya aktivitas belajar mahasiswa.

Pada akhir jam perkuliahan, peneliti mengadakan tes untuk melihat kemampuan awal mahasiswa dengan materi yang telah diberikan. Adapun hasil tes pra siklus, diperoleh rata-rata kemampuan pemahaman mahasiswa termasuk dalam kategori rendah ( hanya 59,8), sedangkan prosentase ketuntasan hanya 34,2 \% yang tuntas dengan patokan nilai 60. Beberapa masih menunjukkan perulangan kesalahan akan pemahaman konsep yang telah dijelaskan pengampu pada saat kegiatan inti dari pembelajaran, seperti:

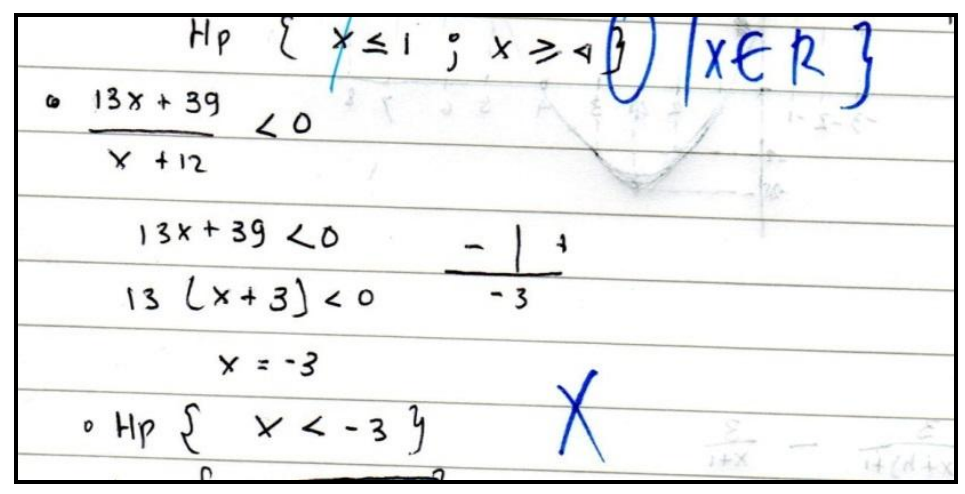

kesalahan tersebut banyak dilakukan mahasiswa, yakni mengalikan ke dua sisi dengan $(x+12)$, sehingga diperoleh penyelesaian hanya dari pembilang, menganggap proses yang sama saat menyelesaikan persamaan. Kesalahan tersebut tentunya tidak bisa diabaikan. Sedangkan prosentase hasil pengamatan terhadap karakter belajar mahasiswa pada tahap pra siklus ini menunjukkan capaian sebesar 42,1\%, dan kategori termasuk dalam kategori cukup Data tersebut diambil dari hasil amatan dari para observer dengan menggunakan triangulasi sumber sebagai validasi data.

Hasil pra siklus tesebut menguatkan dugaan sementara peneliti untuk meningkatkan kemampuan pemahaman mahasiswa dan karakter belajar seperti karakter jujur, disiplin, kerja keras, kreatif, mandiri, demokratis, memiliki rasa ingin tahu, menghargai prestasi, bersahabat, tanggung jawab dengan menggunakan strategi ARCS dan pemberian scaffolding pada mahasiswa Prodi Pendidikan Fisika peserta mata kuliah Matematika Dasar.

\section{Tindakan Siklus 1}

Siklus 1 dilaksanakan dalam 3 pertemuan diadakan pada setiap hari Rabu jam 12.20 -14.50 (3x50 menit) di ruang 5402 dengan materi Limit Fungsi dan Kontinuitas. Perencanaan untuk siklus 1 meliputi kegiatan sebagai berikut : penyusunan RPP, silabus, pembuatan media pembelajaran, penyusunan soal kuis yang didesain untuk mengungkap kemampuan pemahaman matematika mahasiswa,serta penyusunan lembar pengamatan karakter belajar mahasiswa. Desain perangkat tersebut telah dilakukan validasi isi oleh rekan sejawat sebagai professional judgment. Adapun tahap pelaksanaan, kegiatan pembelajaran yang dilakukan adalah sebagai berikut :

- Pada fase Attention, dosen membuka kelas dengan memberikan pemanasan berpikir tentang limit fungsi pada fungsi polinom dan fungsi rasional. Dengan memberikan kontradiksi pada 2 kasus tersebut diharapkan mahasiswa mengetahui apa definisi limit sebagai suatu pendekatan. Pengkaitan topik juga dilakukan pengampu dengan memberikan tabel isian tentang harga fungsi di berbagai titik yang mendekati c sebagai pengantar 
menuju definisi $\lim _{x \rightarrow c} f(x)=L$. Pada pertemuan kedua, sebagai fase Attention, dosen memberikan pertanyaan tentang limit kanan kiri sebagai apersepsi dan pemanasan berpikir tentang definisi kontinu secara intuitif. Dengan memberikan kontradiksi pada 3 gambar yang mencerinkan kontinuitas dan diskontinuitas diharapkan mahasiswa mengetahui apa definisi kontinuitas pada titik.

- Pengkaitan topik juga dilakukan pengampu dengan gambar dan konsep limit sebagai pengantar menuju definisi $\lim _{x \rightarrow c} f(x)=f(c)$ sebagai pengantar definisi limit di titik $x=c$. sedang pada kontinuitas selang pengampu mencoba memberikan kaitan dari beberapa teorema sebagai fase Relevance. Pengampu menyampaikan tujuan pembelajaran sebagai kriteria sukses bagi peserta didik dan proses belajar. Pengampu juga memberikan modul belajar yang didesain dengan pemberian scaffolding pada setiap langkah sehingga mahasiswa mampu menemukan $\varepsilon$ dan $\delta$ sebagai pengantar menuju definisi limit secara formatif dan mengetahui arti langkah pembuktian.Sedang pada pertemuan 2, pada kontinuitas selang pengampu mencoba memberikan penjelasan beberapa teorema kontinuitas dan meminta mahasiswa mampu menjabarkan pemikirannya mengapa dan bagaimana teorema tersebut digunakan dalam penyelasaian masalah kontinuitas .

- Pada tahapan Sastisfaction, pengampu juga menciptakan peluang sukses tercapainya tujuan pembelajaran dengan memberikan arahan baik lewat media modul belajar maupun bimbingan langsung serta mendorong dan memfasilitasi siswa mengaplikasikan konsep/keterampilan dalam contoh permasalahan yang baru

- Pada fase Confidence tahapan ini pengampu juga mendorong mahasiswa untuk menjelaskan konsep yang dipelajari dengan kalimat mereka sendiri dan memberikan penguatan atas definisi atau penjelasan sebagai dasar diskusi.

Dari hasil observasi di atas, di hampir ke 19 kategori karakter belajar mahasiswa, menurut indikator Suharsimi Arikunto dan Safruddin Ceppi ( 2008) sudah termasuk dalam kategori sedang ( 63,4\% dan 64,5\%). Dengan demikian, sebenarnya dari semester awal mahasiswa sudah memiliki modal yang baik dalam menunjang keberhasilan belajarnya. Namun dari beberapa indikator yang masih dibawah harapan seperti karakter kreatif dalam menyelesaikan masalah, karakter pengembangan rasa ingin tahu, tanggung jawab terhadap kelompok masih perlu ditingkatkan. Hal tersebut juga dapat digambarkan dalam histogram berikut :

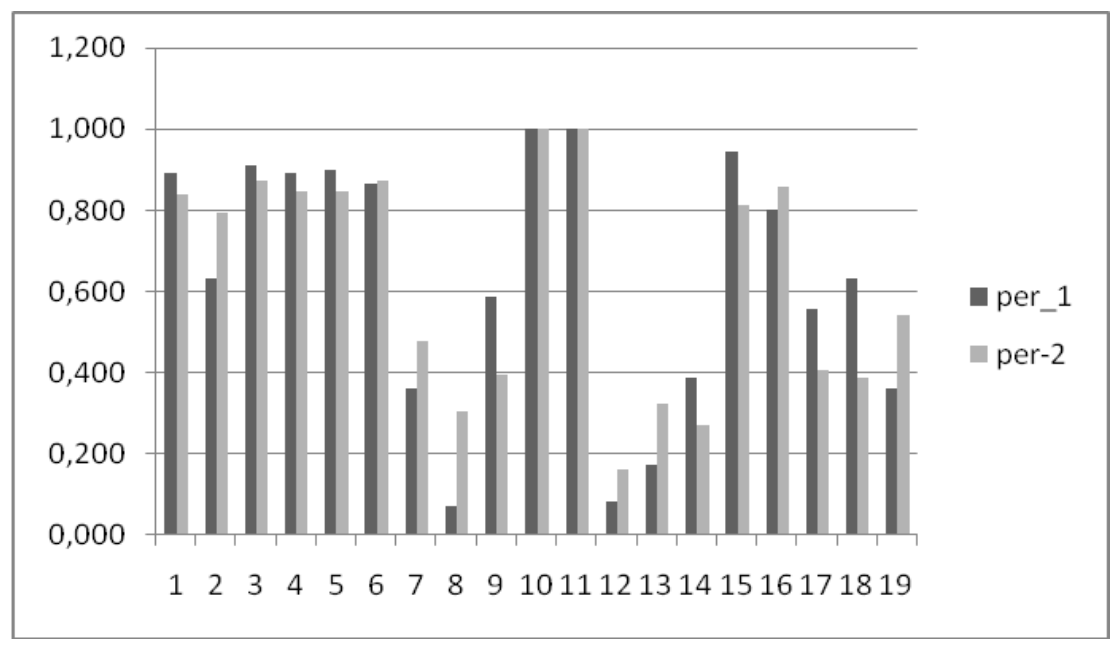

Namun kontradiksi dengan hasil pengamatan pada karakter belajar mahasiswa, ditinjau dari aspek pemahaman konsep matematika, hasil belajar mahasiswa untuk kemampuan pemahaman masih ada 23,6\% dari 
menunjukkan kekurang pahaman mahasiswa akan konsep definisi limit secara formal. Dan meski dari prosentase ketidak tuntasan masih tergolong kecil, namun kekurangpahaman mahasiswa masih perlu menjadi perhatian bagi pengampu. Sebagai contoh :

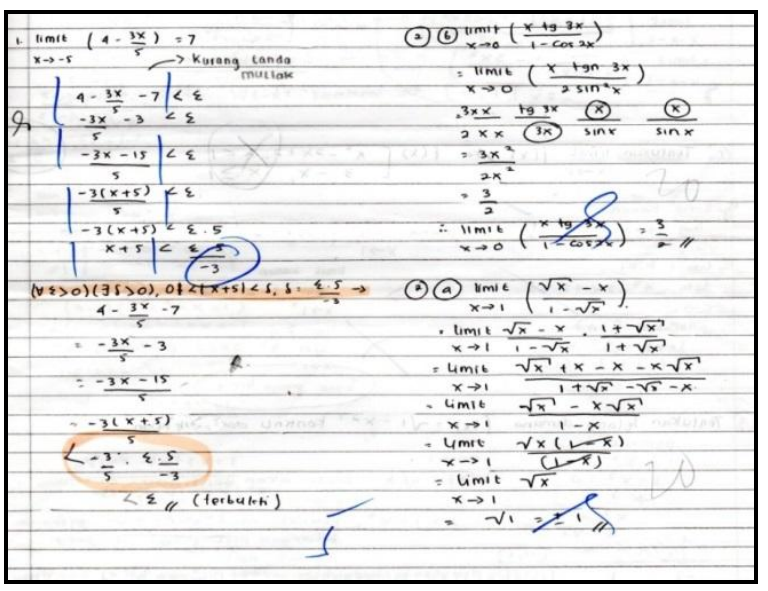

\begin{abstract}
Tampak bahwa mahasiswa tersebut telah menulis syarat harga $\varepsilon$ dan $\delta$ yang harus lebih besar dari nol (untuk sembarang $\varepsilon>0$ dapat ditemukan $\partial>0$ ), namun mahasiswa masih menyebutkan bahwa harga $\delta$ yang dipilih kurang dari nol $(\delta<0)$. Hal ini mengindikasikan bahwa pemahaman mahasiswa terhadap konsep limit masih kurang, pemahaman akan makna definisi dan simbol yang ada masih terpecah-pecah dengan teknik penghitungan semata.
\end{abstract}

Dari prosentase sebesar 23,6 \% mahasiswa yang masih belum tuntas pada materi tersebut dan rerata kelas yang juga masih rendah (61), sedangkan materi limit fungsi dan kontinuitas adalah dasar bagi mahasiswa untuk belajar konsep Matematika Dasar selanjutnya, sehingga peneliti belum merasa cukup dan masih merasa perlu untuk melanjutkan ke siklus 2

\title{
Tindakan Siklus 2
}

Berdasarkan hasil refleksi siklus I, maka perencanaan tindakan untuk siklus II mengalami sedikit perubahan seperti:

- Lebih memotivasi mahasiswa untuk lebih aktif dalam kegiatan pembelajaran, terutama saat kegiatan presentasi kelompok. Memotivasi mahasiswa untuk ikut berpartisipasi dalam merekontruksi masalah yang diberikan pada kelompok dan memberikan banyak kesempatan bagi mahasiswa untuk menunjukkan hasil diskusinya, bukan hanya perwakilan kelompok.

- Mengoptimalkan fungsi sebagai fasilitator dan memberikan kesempatan yang luas kepada siswa dalam kegiatan lisan untuk bertanya, menjawab pertanyaan serta menyampaikan pendapatnya.

- Memberikan waktu bagi seluruh mahasiswa untuk menyelesaikan tugas yang mungkin diambil dari soal referensi lain dan melakukan pemeriksaan terhadap tugas-tugas tersebut.

Dari hasil refleksi dan evaluasi terhadap hasil pelaksanaan siklus 1, maka diperlukan perbaikan pengelolaan dan pelaksanaan pembelajaran pada siklus 2. Pelaksanaan tindakan 2 dilaksanakan pada tanggal 23 September - 21 Oktober 2015. Siklus 2 terdiri dari 3 kali pertemuan dan 1 kali pertemuan untuk pelaksanaan tes. Materi pada siklus 2 adalah Turunan dan Penggunaan turunan dalam pemecahan masalah.

- Pada kegiatan awal sebagai fase Attention, dosen membuka kelas dengan memberikan pemanasan berpikir, mengajukan pertanyaan tentang proses faktual yang terkait dengan masalah sehari-hari terkait dengan topik bahasan untuk memunculkan rasa ingin tahu mahasiswa tentang kasus yang dapat diselesaikan dengan turunan. Untuk pertemuan1, dosen memberikan contoh dari kecepatan dan gradien. Diharapkan mahasiswa mengetahui keterkaitan limit dengan turunan sebagai topik yang akan dibahas dengan pengalaman belajar yang telah diperoleh pada limit. Untuk pertemuan ke 2, dosen membuka kelas dengan memberikan pertanyaan sebagai pemanasan berpikir atas 2 kasus yang berbeda seperti tentukan $\frac{d y}{d x}$ dari $\quad y=x^{35}+20 x-3$ dan $\frac{d y}{d x}$ dari 
$y=(x+20)^{35}$, dengan memberikan 2 kasus diharapkan mahasiswa mengetahui perlunya teknik turunan yang bukan hanya pada aturan turunan fungsi polinomial namun juga pelibatan fungsi implisit yang tidak mungkin diselesaikan dengan aturan turunan fungsi polinomial tersebut. Dan pada pertemuan ke 3, pengampu memberikan apersepsi tentang masalah arti titik ekstrem dan pemanasan berpikir tentang ada tidaknya nilai maksimum atau minimum pada fungsi $y=\frac{1}{x}$ yang tanpa pembatasan domain dengan ada tidaknya nilai maksimum atau minimum pada fungsi $y=\frac{1}{x}$ pada [1.3]. Dengan memberikan perbandingan pada 2 kasus tersebut diharapkan mahasiswa mengetahui syarat suatu fungsi mencapai maksimum/ minimum (teorema kewujudan maksimum minimum).

- Pada fase Relevance, pengampu menyampaikan tujuan pembelajaran sebagai kriteria sukses bagi peserta didik dan proses belajar. Pengampu juga memberikan modul belajar yang didesain dengan pemberian scaffolding pada setiap langkah sehingga mahasiswa mampu mengkaikan limit dengan turunan dan pembuktian definisinya. Mahasiswa pada pertemuan ini juga diharapkan mampu menggunakan aturan turunan kelompok fungsi polinomial, fungsi polinomial berpangkat, fungsi pecah, fungsi trigonometri dan variasinya yang melibatkan aturan penurunan $x^{n}$, aturan pangkat, aturan perkalian dan aturan pembagian serta penggunaan turunaan. Pada tahapan ini pengampu juga menciptakan peluang sukses tercapainya tujuan pembelajaran dengan memberikan arahan baik lewat media modul belajar maupun bimbingan langsung serta mendorong dan memfasilitasi siswa mengaplikasikan konsep/keterampilan dalam contoh permasalahan yang baru (Sastisfaction).

- Pada fase Confidence tahapan ini pengampu juga mendorong mahasiswa untuk menjelaskan konsep yang dipelajari dengan kalimat mereka sendiri, meminta bukti dan klarifikasi jawaban mahasiswa, mendengar penjelasan antar mahasiswa, dan memberikan penguatan atas definisi atau penjelasan sebagai dasar diskusi dan memberikan penghargaan terhadap kerja sama anggota dalam team work

Adapun hasil observasi karakter belajaran mahasiswa saat pembelajaran adalah sebagai berikut (dalam rataan prosentase dari 3 kali pertemuan), menurut indikator Suharsimi Arikunto dan Safruddin Ceppi ( 2008) sudah termasuk dalam kategori tinggi. Sebagai visualisasi histogram :

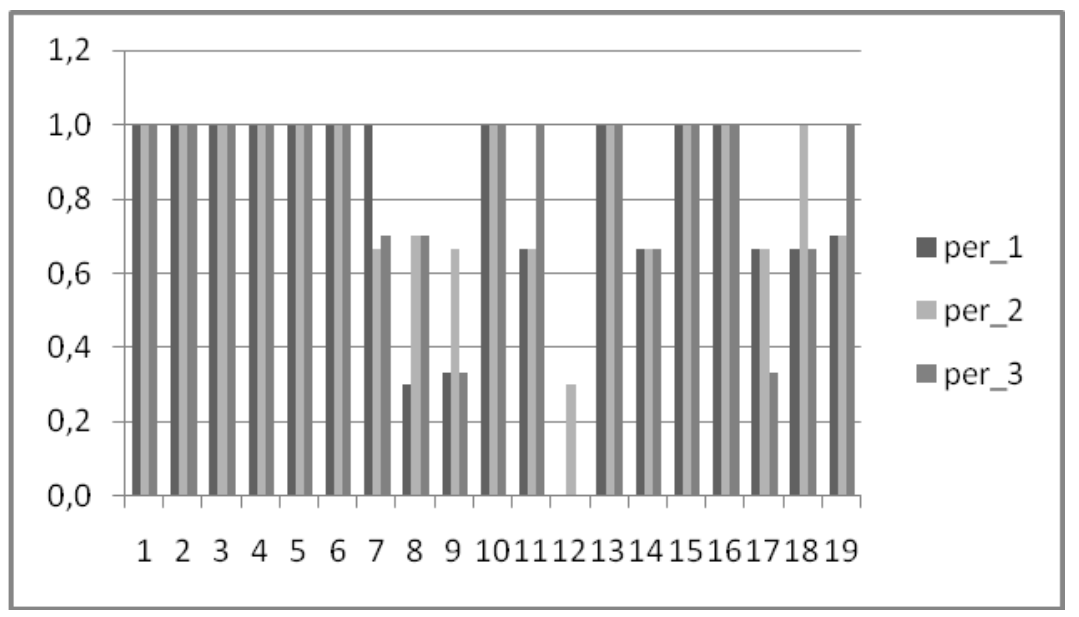

Meski terdapat prosentase dari indikator karakter belajar yang menurun pada pertemuan ketiga dari pertemuan kedua. Hal tersebut dimungkinkan karena pada pertemuan ketiga materi perkuliahan adalah penggunaan turunan dalam menggambar grafik. Keterbatasan papan tulis sebagai media presentasi dan panjangnya penyelesian untuk 
menggambar grafik membuat pengampu tidak bisa meminta mahasiswa menunjukkan sikap demokratis yang ditunjukkan dengan keharusan mempresentasikan berdasarkan hasil diskusi kelompok/kelas.

Prosentase dari kemampuan pemahaman mahasiswa berdasar dari soal tes kuis untuk siklus 2 adalah sebesar $82,6 \%$, yang berarti telah memenuhi indikator capaian yang telah ditetapkan. Dan rataan kelas telah mencapai 81.1 yang tergolong tinggi. Harapan peneliti dengan rataan yang tinggi tersebut, maka mahasiswa tidak kesulitan saat mempelajari konsep integral yang memerlukan pemahaman konsep turunan.

Secara keseluruhan tindakan dari pra siklus, siklus 1 dan 2 , tampak bahwa pada chart berikut :

Dari hasil tes yang mengungkapkan kemampuan pemahaman mahasiswa juga menujukkan kenaikan rerata yang cukup signifikan. Dari visualisasi histogram tampak sebagai berikut :

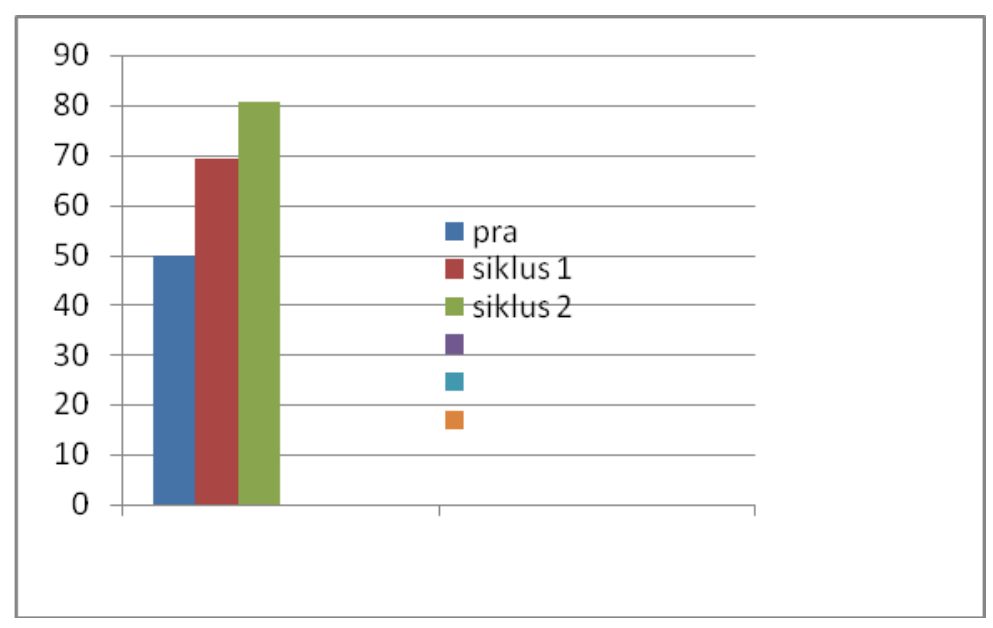

Dari visualisasi histogram tersebut tampak bahwa saat kegiatan pra siklus hasil belajar yang mengungkap kemampuan pemahaman mahasiswa prosentase ketuntasan belajar hanya 39, $5 \%$. Meskipun sebelum pelaksanaan tes, mahasiswa telah diberikan materi yang berkaitan dengan tes tersebut, namun ternyata hasil belajar belum cukup bagus. Rasa keingintahuan yang ditunjukkan dengan tanya jawab, diskusi kelas, serta kemandirian dalam melaksanakan tugas dengan persiapan referensi yang belum tampak dimungkinkan menjadikan hasil capaian belajar mahasiswa kurang optimal.

Namun dari histogram di atas tampak bahwa prosentase ketuntasan kemampuan pemahaman menunjukkan hasil yang cukup tinggi pada siklus 1 dan 2 yakni sebesar 82,6 \%, yang berarti masih terdapat 17,4\% mahasiswa (7 mahasiswa ) yang masih perlu remidi dan rataan kelas juga telah mencapai 81,1. Harapan peneliti dengan rataan yang tinggi tersebut, maka mahasiswa tidak kesulitan saat akan mempelajari konsep integral yang memerlukan pemahaman konsep turunan.

Sedangkan untuk hasil belajar yang afektif, yakni pembentukan karakter belajar mahasiswa, rata-rata prosentase pembentukan karakter belajar mahasiswa menunjukkan respon yang meningkat, dari $42.1 \%$ saat pra siklus, menjadi $63,7 \%$ pada siklus 1 dan meningkat menjadi $81,4 \%$ pada siklus 2 . Meski terdapat pula indikator yang mengalami penurunan seperti pada indikator sikap demokratis yang ditunjukkan dengan sikap saat mempresentasikan hasil.

Adapun visualisasikan hasil pembentukan karakter belajar untuk 2 siklus tindakan tampak seperti gambar di bawah : 


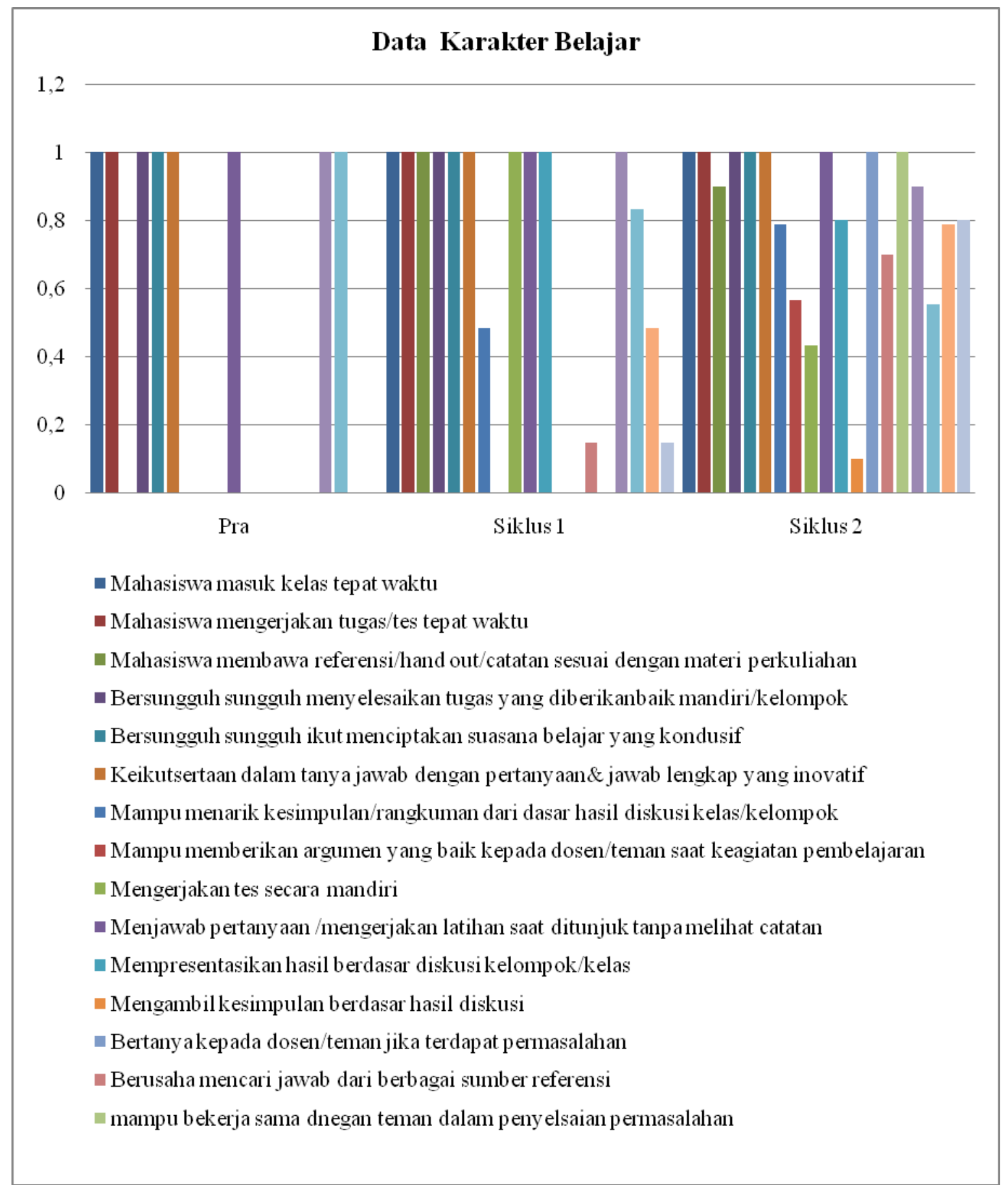

Dari hasil di atas, sebagai salah satu tujuan pendidikan matematika yakni pembentukan karakter belajar, sudah sepatutnya dalam proses pembelajaran matematika (penggunaan model pembelajaran ) perlu diperhatikan karakter sebagai faktor afektif peserta didik terhadap matematika. Karena dari pendapat para pakar yang dirangkum oleh Norjoharuddeen (dalam Fajar Shodiq 2008) juga menyatakan : bahwa terdapat dua faktor yang dapat mempengaruhi proses pembelajaran matematika pada diri setiap siswa, yaitu: (1) faktor kognitif dan (2) faktor non-kognitif. Faktor kognitif sendiri berkait dengan kemampuan otak dalam berpikir, kemampuan mengingat ataupun bernalar. Sedangkan faktor non-kognitif berkait dengan kemampuan di luar kemampuan otak dalam berpikir. Bagaimana siswa akan berhasil jika siswa menunjukkan sikap tidak ingin tahu, tidak berminat terhadap matematika, tidak ingin ikut terlibat dalam kegiatan belajar matematika/pemecahan masalah, tidak merasa bertanggung jawab dengan hasil belajarnya? Sebagai faktor afektif, sikap berkaitan dengan perasaan atau 
kecenderungan seseorang untuk melakukan sesuatu. Dengan membentuk karakter, ternyata berpengaruh pada kecenderungan siswa untuk untuk ikut serta dalam kegiatan pembelajaran yang berpengaruh terhadap prestasi belajar.

\section{SIMPULAN DAN SARAN}

Berdasarkan hasil penelitian ini dapat disimpulkan sebagai berikut.

1. Proses pembelajaran mata kuliah Matematika Dasar dengan strategi pembelajaran ARCS dengan pemberian scaffolding dapat meningkatkan kemampuan pemahaman matematika mahasiswa Prodi Pendidikan Fisika 2015/2016 dan pembentukan karakter belajar sebagai faktor afektif belajar matematika. Adapun inti dari pembelajaran dengan strategi pembelajaran ARCS dengan pemberian scaffolding adalah:

- Attention

Memunculkan perhatian didorong oleh rasa ingin tahu. Rasa ingin tahu ini dapat diberikan dosen saat pendahuluan pembelajaran dengan memberikan pemanasan berpikir dengan dirangsang melalui pertanyananpertanyan/ pemberian fakta baru, lain dengan yang sudah ada, dan kontradiktif. Dapat pula pengampu memberikan apersepsi berupa pertanyaan yang terkait dengan konsep yang telah dimiliki, mengkaitkan topik dengan pengalaman siswa.

- Relevance

Menstimulasi keingintahuan siswa. Hal tersebut dapat dilakukan dengan jalan menyajikan berbagai kasus yang mengandung kontradiksi yang relevan dengan isi pembelajaran. Memelihara iklim motivasi belajar mahasiswa (keingintahuan) yang positif melalui penyusunan tugas-tugas belajar yang memberikan kesempatan kepada siswa untuk mencapai keberhasilan.. Dalam pelaksanaanmya, tugas belajar tersebut dapat dilakukan dengan jalan mengkombinasikan kegiatan yang bersifat kooperatif, kompetitif dan individual. Dalam kaitan tindakan tersebut, peneliti memilih untuk memberikan scaffolding bagi mahasiswa sebagai alat untuk mencapai keberhasilan belajarnya sehingga mahasiswa mampu mencapai Zone Proximum Development dari teman sejawat maupun dari modul.

- Confident

Dalam tahapan tersebut, pengampu harus menciptakan peluang sukses tercapainya tujuan pembelajaran, minimalisasi stres siswa dengan memberikan arahan baik lewat media modul belajar maupun bimbingan, meningkatkan kreativitas dan kesempatan siswa untuk meningkatkan dirinya

- Satisfaction

Memberikan penghargaan terhadap kerja sama anggota dalam team work

Motivasi mahasiswa sangat dipengaruhi oleh pencapaian hasil belajar yang diperoleh siswa. Oleh karena itu pemilihan teknik motivasi tepat untuk memenuhi kebutuhan siswa dalam mencapai prestasi belajar yang optimal.

2. Penerapan pembelajaran dengan strategi ARCS dengan pemberian scaffolding dapat meningkatkan kemampuan pemahaman. Hal ini terbukti dari hasil observasi siklus I dan hasil observasi siklus II bahwa prosentase ketuntasan hasil kemampuan pemahaman akan konsep matematika mahasiswa meningkat dari 39, $5 \%$ meningkat menjadi $77,4 \%$ ( pada siklus 1) dan $82,6 \%$ ( pada siklus 2) 
3. Penerapan pembelajaran dengan strategi ARCS dengan pemberian scaffolding juga meningkatkan hasil belajar afektif mahasiswa yakni pembentukan karakter belajar mahasiswa. Hal ini terbukti dari hasil observasi siklus I dan hasil observasi siklus II bahwa rata-rata prosentase pembentukan dari kategori rendah ( $42,1 \%$ saat pra siklus) menjadi tinggi ( $81,4 \%$ saat siklus 2 )

Penting pula bagi guru/dosen lebih memperhatikan karakter materi, persepsi yang telah dimiliki mahasiswa akan suatu materi/konsep dan kesulitan mahasiswa dalam belajar sehingga dengan pemilihan metode pembelajaran yang tepat mampu meningkatkan hasil belajarnya. Karena meski sudah pada tataran mahasiswa, dimungkinkan perlunya memberikan bantuan, memfasilitasi pebelajar untuk mencapai rasa confidencenya, sehingga lebih memotivasi pebelajar yang pada akhirnya diharapkan mampu meningkatkan hasil belajarnya.

\section{DAFTAR PUSTAKA}

Daryanto, Suryatri Darmiatun. 2013. Implementasi Pendidikan Karakter di Sekolah. Yogyakarta: Penerbit Gama Media

Endang Mulyatiningsih. 2011. Metode Penelitian Terapan Bidang Pendidikan. Bandung : Alfabeta

Hudoyo, Herman. 1985. Teori Belajar Dalam Proses Belajar-Mengajar Matematika. Jakarta. Depdikbud

Martini Jamaris. 2012. Orientasi Baru dalam Psikologi Pendidikan. Bogor : Penerbit Ghalia Indonesia

Seriwati dalam http:// sumut.kemenag.go.id Pendidikan Karakter, diakses tanggal 2 April 20015

Suharsimi Arikunto dan Safrudin Ceppi. 2011. Penelitian Tindakan Kelas. Jakarta: Bumi Aksara.

https://www.ipfw.edu/celt). The ARCS Model: Attention, Relevance, Confidence, and Satisfaction diakses 27 Juni 2015

https://sphweb.bumc.bu.edu. Learning Theory : ARCSintegrated_handout...diakses 23 Oktober 2015 